\title{
Phenolic Content, Antioxidant, Antimicrobial and Cytotoxic Activities of Ethanolic Extract of Salix alba
}

\author{
Ghassan Mohammad Sulaiman, Nehia Nima Hussien, \\ Thorria Raddam Marzoog and Hussain Abood Awad \\ Department of Applied Science, Biotechnology Division, University of Technology, Baghdad, Iraq
}

Received 2012-07-23, Revised 2013-01-27; Accepted 2013-02-15

\begin{abstract}
The total phenolic content, antioxidant, antimicrobial and cytotoxic activities of hot ethanolic extract of Salix alba bark were investigated. The antioxidant properties and the total phenolic contents of the extract were assessed by 1, 1-Diphenyl- 2-Picrylhydrazyl (DPPH) free radical scavenging and FolinCiocalteu methods, respectively. The extract showed significant antioxidant activity and antimicrobial activities against Staphylococcus aureus, Pseudomonas aeruginosa and Candida albicans. The highest effect was observed on C. albicans, followed by S. aureus then P. aeruginosa. While, Escherichia coli and Klebsiella pneumoniae were not affected. The cytoxicity of $S$. alba extract against the Human Leukemia (HL-60) cell line was evaluated, it had been noticed that the extract significantly reduced the viability of HL-60 cells in a dose- and time-dependent response relationship. Findings from the present study indicate that extract is highly cytotoxic to HL-60 cells. The antimicrobial and cytotoxic activities of $S$. alba extract seemed to be positively correlated with their antioxidant potentials.
\end{abstract}

Keywords: Phenolics, Antioxidant, Antimicrobial, Cytotoxicity

\section{INTRODUCTION}

Since the beginnings of civilization, humans have used natural products for healing diseases that afflict them. Plants are biochemical labs that produce inside their cells a variety of complex substances with numerous active compounds. With the advent of the pharmaceutical chemistry at the beginning of the nineteenth century, plants became the primary source of substances for drug development (Rates, 2001).

White willow (Salix alba L.), is a willow belongs to the genus salix and family salicaeae. Willows range from prostrate shrubs to large tree over $30 \mathrm{~m}$ high, but most are shrubs or small trees. White willow which is also known as the salicin willow, has been used for its health benefits for thousands of years (Saller et al., 2008).

Records suggest that, as far back as 6000 years ago, white willow was used in Mesopotamia. Subsequently, ancient peoples recorded the use of white willow to cure pain and inflammation, including the Assyrian, Babylonian, Sumerian, Egyptian, Chinese, Greek and Roman civilizations. Hippocrates recommended chewing willow bark to patients suffering from fever, inflammation and pain. He also prescribed a brew of willow leaves to ease the excruciating pains of childbirth. Since that time, white willow has continued to be used to ease pain and inflammation (Mahdi et al., 2006).

Willow bark has been used to treat many different kinds of pain, including rheumatic pain, back pain, toothache and menstrual cramps. It is also used to relieve sore throat, fever and headache associated with upper respiratory tract infections and influenza (Schmid et al., 1998).

In spite of the long and compelling history of traditional use of willow bark, study of its medical properties is still needed. Thus, the objective of the present

Corresponding Author: Ghassan Mohammad Sulaiman, Department of Applied Science, Biotechnology Division, University of Technology, Baghdad, Iraq 
study was to investigate the antimicrobial activity of ethanol extract of $S$. alba bark, the anti proliferative activity of Human Leukemia (HL-60) cell line and to determine its total phenolic content and the antioxidant activity.

\section{MATERIALS AND METHODS}

\subsection{Extraction Methods}

Plant barks commonly used in herbal medicine were dried and pulverized with motor and pestle or electric mill. The fine powder of plant parts were extracted with boiled ethanol by soxholet for $7 \mathrm{~h}$. The solution was filtered through Whatman filter paper using a Buchner funnel under vacuum. The filtrate was then evaporated using a rotary evaporator under vacuum at $40^{\circ} \mathrm{C}$ to obtain the bark extract. Then, the resulting extract was stored, protected from light in a refrigerator at $4{ }^{\circ} \mathrm{C}$ in a glass container until use.

\subsection{Determination of Total Phenolics Spectrophotometrically}

Total phenolic compound concentrations were determined spectrophotometrically (Mohammadzadeh et al., 2007). The PE $(0.1 \mathrm{~mL})$ was diluted with ultra pure water $(7.9 \mathrm{~mL})$ at a concentration of $10 \mathrm{mg} \mathrm{mL}^{-1}$. FolinCiocalteu reagent $(0.5 \mathrm{~mL})$ was then added and the contents were mixed thoroughly. After $1 \mathrm{~min}, 0.2 \mathrm{~mL}$ of sodium carbonate solution was added and the mixture was mixed thoroughly. The absorbance of blue color produced solution was measured at $765 \mathrm{~nm}$. Total phenolic content $\left(\mathrm{mg} \mathrm{g}^{-1}\right)$ was estimated using a standard curve for Gallic acid (GAE) concentration. Three measurements were performed and the mean was adopted.

\subsection{Free Radical Scavenging Activity}

The free radical scavenging activity of $S$. alba extract was measured with DPPH assay (Chen et al., 2004). Based on this assay, equal volumes $(0.5 \mathrm{~mL})$ of DPPH $(60 \mu \mathrm{M})$ and each PE $\left(10,50\right.$ or $\left.100 \mu \mathrm{g} \mathrm{mL}^{-1}\right)$ were mixed in a cuvette and allowed to stand for $30 \mathrm{~min}$ at room temperature. Then, the absorbance was read at $517 \mathrm{~nm}$ in a UV/VIS Lambda 19 spectrophotometer. The absorbance of control (DPPH solution) was also read. The percentage of DPPH discoloration of the sample was calculated according to the following formula:

$$
\begin{aligned}
& \text { Percentage of Decolouration }= \\
& \left(\frac{\text { Control Absorbance - Sample Absorbance }}{\text { Control Absorbance }}\right) \times 100
\end{aligned}
$$

\subsection{Antimicrobial Assay}

Antimicrobial activity of $S$. alba extract was determined by the agar-well diffusion method. Four bacterial strains and one yeast were used in present study, they were Staphylococcus aureus (Gram positive), Escherichia coli, Pseudomonas aeruginosa, Klebsiella pneumoniae (Gram negative) and Candida albicans (yeast). The antimicrobial activity was performed using nutrient agar for bacteria and YEPD Agar for yeast. The cell culture suspension was adjusted by comparing against $0.4-0.5$ McFarland scale standard. These suspensions $(100 \mathrm{~mL})$ of each target strain were spread on the plates. For the investigation of the antimicrobial activity, the extract of $S$. alba were weighed and dissolved with distilled water to obtain $10,20,40,60$ or $80 \mathrm{mg} \mathrm{mL}^{-1}$ extract concentration. Each sample $(100 \mathrm{~mL})$ was filled into the wells of agar plates directly. The diameter of the inhibition zone ( $\mathrm{mm})$ was measured after overnight incubation. All samples were tested in triplicate. Controls included solvent without plant extract.

\subsection{Viability of Tumor Cells}

The study was performed on cells human promyeloid leukemia (HL-60). The cells at density of $1.5 \times 10^{5}$ were cultured in RPMI-1640 medium supplemented with $10 \%$ heat-inactivated Foetal Bovine Serum (FBS), 2 mM Lglutamine, $10 \%(\mathrm{v} / \mathrm{v})$ inactivated fetal bovine serum, 100 $\mu \mathrm{g} \mathrm{mL} \mathrm{m}^{-1}$ penicillin and $100 \mu \mathrm{g} \mathrm{mL} \mathrm{m}^{-1}$ streptomycin and incubated in a humidified atmosphere of $5 \% \mathrm{CO} 2$ at $37^{\circ} \mathrm{C}$ in 24-well flat-bottom culture plates. After $24 \mathrm{~h}$, the six concentrations $\left(1,2,4,6,8\right.$ or $\left.10 \mu \mathrm{g} \mathrm{mL}^{-1}\right)$ of $S$. alba extract were added in triplicates of each. Culture medium was used instead of the extract for the negative control. The plates were incubated at $37^{\circ} \mathrm{C}$ in the presence of $5 \%(\mathrm{v} / \mathrm{v})$ $\mathrm{CO}_{2}$ for 6,12 and $24 \mathrm{~h}$. The cells were tested for their viability using the trypan blue exclusion test (Bennett et al., 1976). Two hundred cells were counted and the percentage of viable cells was estimated.

\subsection{Statistical Analysis}

Data were statistically analyzed using SPSS statistical software. Level of significant was assessed by using the Analysis of Variance (ANOVA) test. The level of significance was shown using the Least Significant Difference (LSD) test. Values are given as mean \pm standard deviation. "P" values $<0.05$ were considered statistically significant.

\section{RESULTS}

The concentration of phenolic content in ethanolic extract of the $S$. alba bark is presented in Table 1 and showed $162.00 \pm 14.90 \mathrm{mg} \mathrm{g}^{-1}$ of GAE. The free radical scavenging activities of different concentrations of $S$. alba bark extract are also shown in Table 1. In this study the pattern of DPPH radicals inhibition showed a concentration-dependent manner for $S$. alba extract. 
Ghassan Mohammad Sulaiman et al. / American Journal of Biochemistry and Biotechnology 9 (1): 41-46, 2013

Table 1. Total phenolics and DPPH free radical scavenging activity (FRSA) of $S$. alba bark extract (parameters as Mean \pm SD) DPPH free radical scavenging activity

\begin{tabular}{|c|c|c|c|c|c|c|c|}
\hline \multirow{2}{*}{$\begin{array}{l}\text { S. alba } \\
\text { Extract }\end{array}$} & \multirow{2}{*}{$\begin{array}{l}\text { Total phenolics } \\
\text { concentration } \\
\mathrm{mg} \mathrm{g}^{-1}\end{array}$} & \multicolumn{2}{|l|}{$10.0 \mu \mathrm{g} \mathrm{mL}^{-1}$} & \multicolumn{2}{|l|}{$50.0 \mu \mathrm{g} \mathrm{mL}^{-1}$} & \multicolumn{2}{|l|}{$100.0 \mu \mathrm{g} \mathrm{mL}^{-1}$} \\
\hline & & Absorbance* & FRSA & Absorbance* & FRSA & Absorbance* & FRSA \\
\hline Bark & $162.00 \pm 14.90$ & $0.35 \pm 0.10$ & 12.50 & $0.25 \pm 0.08$ & 37.50 & $0.08 \pm 0.05$ & 80.00 \\
\hline
\end{tabular}

* Control absorbance: $0.40 \pm 0.04$

Table 2. Antimicrobial activity of the S. alba bark extract (parameters as Mean \pm SD)

\begin{tabular}{|c|c|c|c|c|c|c|}
\hline \multirow[b]{2}{*}{ Micro-organisms } & \multicolumn{6}{|c|}{ Concentration $\mathrm{mg} \mathrm{mL} \mathrm{m}^{-1}$} \\
\hline & Control & 10 & 20 & 40 & 60 & 80 \\
\hline S. aureus & $6.00 \pm 0.00$ & $14.66 \pm 0.88$ & $16.33 \pm 0.88$ & $19.00 \pm 0.57$ & $21.33 \pm 0.66$ & $22.33 \pm 0.33$ \\
\hline$P$. aeruginosa & $6.00 \pm 0.00$ & $\mathrm{NA}$ & $11.66 \pm 0.66$ & $13.66 \pm 2.18$ & $16.33 \pm 2.02$ & $17.00 \pm 2.51$ \\
\hline E. coli & $6.00 \pm 0.00$ & NA & $\mathrm{NA}$ & & $\mathrm{NA}$ & $\mathrm{NA}$ \\
\hline K. pneumoniae & $6.00 \pm 0.00$ & NA & NA & NA & NA & NA \\
\hline C. albicans & $6.00 \pm 0.00$ & $14.66 \pm 0.88$ & $18.66 \pm 0.33$ & $21.66 \pm 0.33$ & $22.66 \pm 0.33$ & $23.66 \pm 0.33$ \\
\hline
\end{tabular}

* NA: Not Affected

Table 3. The effect of $S$. alba bark extract on the viability of HL-60 cells (parameters as Mean \pm SD)

\begin{tabular}{|c|c|c|c|c|c|c|}
\hline \multirow[b]{2}{*}{ S. alba extract } & \multicolumn{6}{|c|}{ Time of incubation (h) } \\
\hline & $\begin{array}{l}6 \\
\text { Dead }(\%)\end{array}$ & Viable (\%) & $\begin{array}{l}12 \\
\text { Dead }(\%)\end{array}$ & Viable (\%) & $\begin{array}{l}24 \\
\text { Dead }(\%)\end{array}$ & Viable (\%) \\
\hline HL-60+RPMI & $2 \pm 0.16$ & 98 & $3 \pm 0.22$ & 98 & $2 \pm 0.16$ & 98 \\
\hline HL-60+1 $\mu \mathrm{g}$ & $6 \pm 0.30$ & 96 & $8 \pm 0.44$ & 94 & $11 \pm 0.60$ & 93 \\
\hline HL- $60+2 \mu \mathrm{g}$ & $10 \pm 0.22$ & 90 & $15 \pm 2.00$ & 85 & $17 \pm 1.40$ & 87 \\
\hline HL- $60+4 \mu \mathrm{g}$ & $20 \pm 1.22$ & 80 & $26 \pm 1.40$ & 74 & $38 \pm 3.10$ & 38 \\
\hline HL- $60+8 \mu \mathrm{g}$ & $36 \pm 2.20$ & 64 & $44 \pm 1.87$ & 36 & $50 \pm 2.30$ & 50 \\
\hline HL- $60+10 \mu \mathrm{g}$ & $68 \pm 3.23$ & 42 & $72 \pm 3.20$ & 28 & $84 \pm 4.21$ & 16 \\
\hline
\end{tabular}

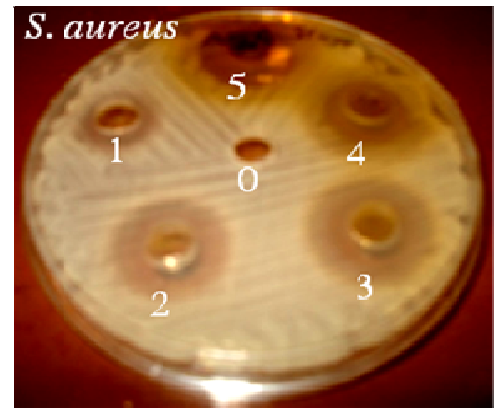

(A)

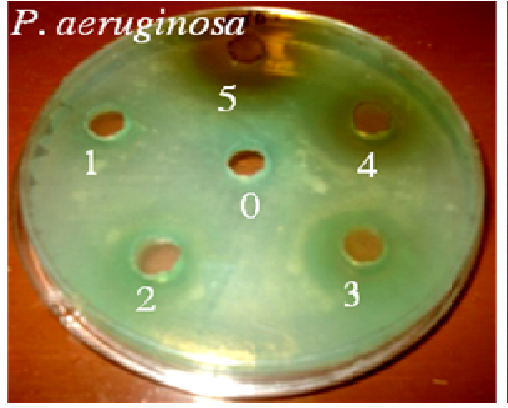

(B)

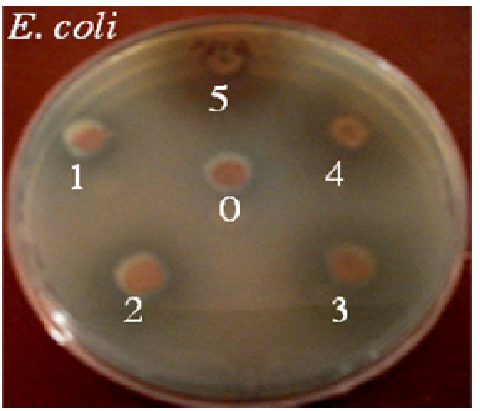

(C)

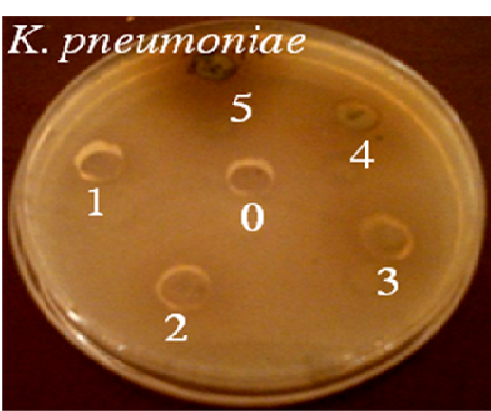

(D)

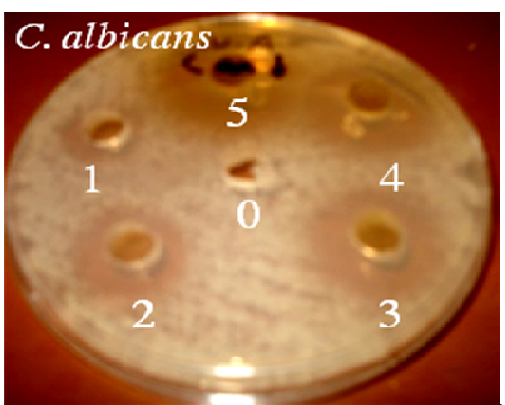

(E)

Fig. 1. Inhibition zone effects of $S$. alba bark extract. Numbers $\left(0,1,2,3,4\right.$ and 5) are control, 10, 20, 40, 60 and $80 \mathrm{mg} \mathrm{mL}^{-1}$, respectively. (A) Staphylococcus aureus (B) Pseudomonas aeruginosa (C) Escherichia coli (D) Klebsiella pneumoniae (E) Candida albicans 
The values of the free radical scavenging activity were $12.50,37.50$ and $80.00 \%$ of 10,50 and $100 \mu \mathrm{g} \mathrm{mL}^{-1}$, respectively.

The well diffusion method was used to determine the inhibition zones of the different concentrations from $S$. alba extract as shown in Table 2 and Fig. 1. The four Gram-positive, Gram-negative bacterial strains and one yeast were used. The result of the inhibitory effect of the extract on the growth of bacteria showed a considerable diversity. As shown in Table 2 and Fig. 1C and D $E$. coli and $K$. pneumoniae were not affected after treatment with $S$. alba extract, while others were affected to various degrees. C. albicans showed the largest inhibition zone with $(23.66 \pm 0.33 \mathrm{~mm})$ at $80 \mu \mathrm{g} \mathrm{mL}$ (Table 2 and Fig. 1E) followed by $S$. aureus $(22.33 \pm 0.33 \mathrm{~mm})$ (Table 2 and Fig. 1A) and finally $P$. aeruginosa $(17 \pm 2.51 \mathrm{~mm})$ (Table 2 and Fig. 1B).

The antiproliferative activity of $S$. alba extract was evaluated in human promyeloid leukaemia cells (HL-60). As shown in Table 3, treatment with S. alba extract at a concentration of $1-10 \mu \mathrm{g} \mathrm{mL}^{-1}$ showed a dose and time dependent decrease in cell viability. The viability of tumor cells after incubation with ethanolic extract of Salix bark were greatly affected ( $84 \%$ cell death) compared to untreated cells ( $2 \%$ cell death) after $24 \mathrm{~h}$ of incubation (Table 3 ).

\section{DISCUSSION}

The results indicated that $S$. alba extract have good free radical scavenging activity and can be used as a radical inhibitor or scavenger, acting possibly as a primary antioxidant. However, the good correlation between the results from total phenolics analysis and the antioxidative assay was observed. Polyphenolic compounds are known to have antioxidant activity and it is likely that the activity of the extract is due to these compounds (Zheng and Wang, 2001; Chen et al., 2002; Luximon-Ramma et al., 2005; Djeridane et al., 2006).

The role of antioxidant is to remove free radicals. One important mechanism through which this is achieved is by donating hydrogen to free radicals in its reduction to an unreactive species. Addition of hydrogen would remove the odd electron feature which is responsible for radical reactivity. The hydrogen-donating activity, measured using DPPH radicals as hydrogen acceptor, showed that there was a significant association could be found between the concentration of extract and percentage of inhibition. The scavenging activity on DPPH radicals has been widely used to determine the free radical-scavenging activity of different matrices by several authors (Pereira et al., 2006; Oliveira et al., 2008; Sulaiman et al., 2011).
In this study, the antimicrobial activity was investigated and exhibited better antimicrobial activity against Gram-positive bacteria than Gram-negative bacteria. These results are in accordance with what has been previously reported of Ficus benghalensis and F. racemosa extract. The activity was highest against $S$. aureus and lowest against $K$. pneumoniae in both the aqueous and ethanolic extracts (Murti and Kumar, 2011).While, our results contradict the effect of Woodfordia fruticosa extract that showes more activity against Gram negative bacteria than Gram positive bacteria (Parekh and Chanda, 2007). However, it is not surprising that there are differences in the antibacterial effects of plant groups, due to the phytochemical differences between species (Murti and Kumar, 2011).

The explanation of Gram-positive bacteria is more susceptible than Gram-negative bacteria may attribute to the differences in their cell wall structure. Gram-negative organisms are considered to be more resistant due to their outer membrane acting as a barrier to many environmental substances, including antibiotics (Kaye et al., 2004). However, the results of this study reveals that the crude ethanolic extract of $S$. alba contain certain constituents like tannins and glycosides with significant antibacterial property which enables the extract to overcome the barrier in bacterial cell wall (Scalbert, 1991; Senthamilselvi et al., 2012). There were no significant difference between the bacterial species and the yeast regarding the effect of the extract on their growth (Table 2). It was found that taninns have antifugal activity (Otshudi et al., 2005). Their activity is probably due to their ability to combine with extracellular and soluble proteins and to combine with fungal cell walls. Nature of these compounds may also disrupt fungal membranes (Tsuchiya et al., 1996).

From antiproliferative activity values againsts HL-60, the viability of cells considerably decreased with increasing doses and time of incubation. The mortality data obtained in these results allow us to predict their potential not only because of the cytotoxic effect, but also in terms of the potential for tumor reduction. However, previous report of El-Shemy et al. (2007) revealed that aqueous extract from willow leaves prevented proliferation of three cancer cell types Acute Myeloid Leukemia (AML), Acute Lymphoblastic Leukemia (ALL) and Ehrlich Ascites Carcinoma Cells (EACC) by causing DNA fragmentation and inducing apoptosis within treated cells. Also, they found that fractions obtaind by polar organic solvents (water and $70 \%$ ethanol) has a major destractive effectes on tumor cells as copmpared with fractions of nonpolar solvents (El-Shemy et al., 2007). It is clear that the antitumor activity of the willow bark was 
mostly due to compounds that are soluble in ethanol. The phenolic compounds, mostly glycosides and many types of tannin will dissolve in ethanol or even water (Bravo, 1998). Therefore, these groups of compounds may contain the major active components for the destruction of leukemia cells.

The willow compounds may bind with receptors on the surface of tumor cells and penetrate into the cells. The cells could be killed through denaturation of some enzymes and proteins that are induced by some phenolic compounds like salicin and saligenin (El-Shemy et al., 2003; 2007). Other mechanisms of HL-60 death may be associated with Willow extract's toxicity like increase of tumor $\mathrm{P}^{53}$ protein expression or stopping the cell cycle at the metaphase (or other phases) and then inhibits cell division (Hostanska et al., 2007).

\section{CONCLUSION}

The result of this study support the folkloric usage of the studied plant and possesses both significant antimicrobial activity and growth inhibition effects in HL-60 cells due to the antioxidant potentials. The results of cancer cell line suggest that it could be use in prevention of cancer while warranting further in vitro and in vivo investigations to understand more about cell death mechanisms.

\section{REFERENCES}

Bennett, J.M., D. Catovsky, M.T. Danniel, D.G. Galton and H.R. Graanlnik et al., 1976. Proposals for the classification of the acute leukaemias. FrenchAmerican-British (FAB) co-operative group. Br. J. Heam., 33: 451-458. PMID: 188440

Bravo, L., 1998. Polyphenols: Chemistry, dietary sources, metabolism and nutritional significance. Nutr. Rev., 56: 317-333. DOI: 10.1111/ j.17534887.1998.tb01670.x

Chen, C.N., M.S. Weng, C.L. Wu and J.K. Lin, 2004. Comparison of radical scavenging activity, cytotoxic effects and apoptosis induction in human melanoma cells by Taiwanese propolis from different sources. Evid. Complement Alternat Med., 1: 175-185. PMID: 15480443

Chen, H.G., Y.G. Yu and O.X. Zeng, 2002. Study on extraction of flavonoids and Alkaloids from lotus leaf. Food Sci., 23: 69-71.

Djeridane, A., M. Yousfi, B. Nadjemi, D. Boutassouma and P. Stocker et al., 2006. Antioxidant activity of some Algerian medicinal plants extracts containing phenolic compounds. Food Chem., 97: 654-660. DOI: 10.1016/j.foodchem.2005.04.028
El-Shemy, H.A., A.M. Aboul-Enein, K.M. Aboul-Enein and K. Fujita, 2007. Willow leaves' extracts contain anti-tumor agents effective against three cell types. Plos One, 2: e178-e178. DOI: 10.1371/journal.pone. 0000178

El-Shemy, H.A., A.M. Aboul-Enein, M.I. Aboul-Enein and K. Fujita, 2003. The effect of willow leaf extracts on human leukemic cells in vitro. J. Biochem. Mol. Biol., 36: 387-389. PMID: 12895297

Hostanska, K., G. Jurgenliemk, A. Nahrstedt, G. Abel and R. Saller, 2007. Willow bark extract (BNO 1455) and its fractions promote apoptosis in human lung cancer cells irrespective their basal level of COX-2, p53 and Bcl-2 genes. Planta Med., 73: SL018- SL018. DOI: 10.1055/s-2007-986736

Kaye, K.S., J.J. Engemann, H.S. Fraimow, E. Abrutyn, 2004. Pathogens resistant to antimicrobial agents: epidemiology, molecular mechanisms and clinical management. Infect. Dis. Clin. North Am., 18: 467511. PMID: 15308273

Luximon-Ramma, A., T. Bahorun, A.M. Soobrattee and O.I. Aruoma, 2005. Antioxidant activities of phenolic, proanthocyanidin and flavonoid components in extracts of cassia fistula. J. Agric. Food Chem., 50: 5042-5047. DOI: 10.1021/jf0201172

Mahdi, J.G., A.J. Mahdi, A.J. Mahdi and I.D. Bowen, 2006. The historical analysis of aspirin discovery, its relation to the willow tree and antiproliferative and anticancer potential. Cell Prolif., 39: 147-55. DOI: 10.1111/j.1365-2184.2006.00377.x

Mohammadzadeh, S., M. Sharriatpanahi, M. Hamedi, Y. Amanzadeh and S.S.E. Ebrahimi et al., 2007. Antioxidant power of Iranian propolis extract. Food Chem., 103: 729-733. DOI: 10.1016/j.foodchem.2006.09.014

Murti, K. and U. Kumar, 2011. Antimicrobial Activity of Ficus benghalensis and Ficus racemosa roots $L$. Am. J. Microbiol., 2: 21-24. DOI: 10.3844/ajmsp.2011.21.24

Oliveira, I., A. Sousa, I.C. Ferreira, A. Bento and L. Estevinho et al., 2008. Total phenols, antioxidant potential and antimicrobial activity of walnut (Juglans regia L.) green husks. Food Chem. Toxicol., 46: 2326-2331. DOI: 10.1016/j.fct.2008.03.017

Otshudi, A.L., S. Apers, L. Pieters, M. Claeys and C. Pannecouque et al., 2005. Biologically active bisbenzylisoquinoline alkaloids from the root bark of Epinetrum villosum. J. Ethnopharmacol., 102: 89-94. DOI: 10.1016/j.jep.2005.05.021 
Parekh, J. and S. Chanda, 2007. In vitro antibacterial activity of the crude methanol extract of Woodfordia fruticosa Kurz. flower (Lythraceae). Braz. J. Microbiol., 38: 204-207. DOI: 10.1590/S151783822007000200004

Pereira, J.A., A.P.G. Pereira, I.C.F.R. Ferreira, P. Valentao and P.B. Andrade et al., 2006. Table olives from Portugal: phenolic compounds, antioxidant potential and antimicrobial activity. J. Agric. Food Chem., 54: 8425-8431. PMID: 17061816

Rates, S.M.K., 2001. Plants as source of drugs. Toxicon, 39: 603-613. DOI: 10.1016/S0041-0101(00)00154-9

Saller, R., J. Melzer and M. Felder, 2008. Pain relief with a proprietary extract of Willow bark in rheumatology. An Open Trial. Schweiz. Zschr. GanzheitsMedizin, 20: 156-162. DOI: 10.5167/uzh13538

Scalbert, A., 1991. Antimicrobial properties of tannins. Phytochemistry, 30: 3875-3883. DOI: 10.1016/0031-9422(91)83426-L

Schmid, B., B.Tschirdewahn, I. Katter, I. Gunaydin, R. Ludtke et al., 1998. Analgesic effects of willow bark extract in osteoarthritis: Results of a clinical double-blind trial. Focus Alternat. Complementary Therapies, 3: 186-186. DOI: $10.1111 / \mathrm{j} .2042-$ 7166.1998.tb00927.x
Senthamilselvi, M.M., D. Kesavan and N. Sulochana, 2012. An anti-inflammatory and anti-microbial flavone glycoside from flowers of Cleome viscosa. Org. Med. Chem. Lett., 2: 19. DOI: 10.1186/21912858-2-19

Sulaiman, G.M., K.W. Al Sammarrae, A.H. Adhiah, M. Zucchetti and R. Frapolli et al., 2011. Chemical characterization of Iraqi propolis samples and assessing their antioxidant potentials. Food Chem. Toxicol., 49: 2415-2421. DOI: 10.1016/j.fct.2011.06.060

Tsuchiya, H., M. Sato, T. Miyazaki, S. Fujiwara and S. Tanigaki et al., 1996. Comparative study on the antibacterial activity of phytochemical flavanones against methicillin-resistant Staphylococcus aureus. J. Ethnopharmacol., 50: 27-34. DOI: 10.1016/03788741(96)85514-0

Zheng, W. and S.Y. Wang, 2001. Antioxidant activity and phenolic compounds in selected herbs. J. Agric. Food Chem., 49: 5165-5170. DOI: $10.1021 / \mathrm{jf0} 10697 \mathrm{n}$ 